\title{
POLA PIKIR DAN PERILAKU KEWIRAUSAHAAN UMKM DI BULELENG, BALI
}

\author{
aNi Luh Putu Eka Yudi Prastiwi, 'Luh Kartika Ningsih, `I Ketut Suardika \\ $a, b, c$ Sekolah Tinggi IImu Ekonomi Satya Dharma Singaraja \\ achayudiprastiwi@gmail.com
}

\begin{abstract}
ABSTRAK
Pola Pikir Dan Perilaku Kewirausahaan UMKM di Buleleng, Bali. Pola pikir dan perilaku kewirausahaan diperlukan sebagai pendorong keberhasilan usaha mikro, kecil dan menengah (UMKM) di Buleleng. Berawal dari pola pikir, ekspektasi akan menjadi nyata melalui perilaku. Pola pikir dan perilaku kewirausahaan digolongkan menjadi tiga bagian yaitu, learning, spiritual dan pengembangan. Penelitian ini bertujuan untuk mengetahui perbedaan pola pikir dan perilaku kewirausahaan UMKM Pribumi dan Tionghoa. Penelitian ini menggunakan metode kuantitatif dengan desain penelitian eksperimen. Metode sampling yang digunakan adalah purposive sampling. Hasil penelitian ini diuji menggunakan Independent Sample T-test menunjukkan bahwa terdapat perbedaan pola pikir dan perilaku antara UMKM Pribumi dan UMKM Tionghoa. Perbedaan terlihat dari segi pengembangan usaha, UMKM Pribumi memiliki jaringan usaha dan kemampuan penetrasi pasar yang lemah sedangkan UMKM Tionghoa mempunyai konsep "Guan Xi" sebagai kunci dari jaringan dan penetrasi pasar yang kuat. Hendaknya UMKM Pribumi mampu menerapkan nilai positif dari konsep Guan Xi.
\end{abstract}

Kata kunci: pola pikir kewirausahaan, perilaku kewirausahaan, UMKM

\section{PENDAHULUAN}

Indonesia memiliki beraneka ragam suku, budaya dan adat istiadat. Masing-masing etnis memiliki keunggulan dan kelemahan. Di Indonesia terdapat berbagai etnis yang tinggal seperti etnis Jawa, Batak, Melayu, Arab, Tionghoa dan lain sebagainya. Keberadaan etnis Tionghoa yang berperan besar dalam bidang ekonomi salah satunya di Buleleng. Masyarakat Tionghoa merupakan kaum minoritas di Buleleng memiliki perkembangan yang sangat pesat dalam bidang perdagangan. Keberadaan masyarakat Tionghoa baik secara langsung maupun tidak langsung sangat mempengaruhi kehidupan sosial dan ekonomi masyarakat pribumi yang berada di sekitar. Pada sektor perdagangan tampak jelas dominasi etnis Tionghoa, keturunan Arab dan India sebagiannya. Sedangkan di lingkungan Pemerintahan didominasi oleh etnis Jawa (Salim, 2006).

Usaha Mikro Kecil dan Menengah (UMKM) merupakan usaha yang paling banyak dijalankan di Kabupaten Buleleng. Peran strategis UMKM dalam pembangunan ekonomi nasional dapat dilihat dari kualitas maupun segi kemampuannya dalam meningkatkan pendapatan dan penyerapan tenaga kerja. Dalam hal ini, UMKM memiliki kemampuan untuk memanfaatkan bahan baku dan menghasilkan barang dan jasa yang dibutuhkan masyarakat luas dengan harga yang terjangkau (Nagel, 2013).

Data tahun 2015-2017 menunjukkan bahwa terjadi ketidakseimbangan antara jumlah UMKM dengan Tingkat Pengangguran di Buleleng. Seharusnya dengan meningkatnya UMKM diharapkan mengurangi anggka pengganguran. Data ditunjukkan pada tabel di bawah ini : 


\section{Tabel 1. Tingkat Pengangguran dan Jumlah UMKM Tahun 2015-2017}

\begin{tabular}{ccc}
\hline Tahun & $\begin{array}{c}\text { Tingkat } \\
\text { Pengangguran }\end{array}$ & Jumlah UMKM \\
\hline $\mathbf{2 0 1 5}$ & $2.04 \%$ & 30.145 \\
\hline $\mathbf{2 0 1 6}$ & $2.05 \%$ & 31.340 \\
\hline $\mathbf{2 0 1 7}$ & $2,41 \%$ & 32.907 \\
\hline
\end{tabular}

Sumber : Dinas Koperasi, Usaha Kecil dan Menengah Kab. Buleleng

Melihat tabel diatas menunjukkan bahwa UMKM belum mampu menyerap tenaga kerja di Kabupaten Buleleng. Diharapkan kedepannya perkembangan UMKM dapat diiringi dengan menurunnya tingkat pengangguran di Kabupaten Buleleng. Jumlah UMKM pada tabel merupakan jumlah keseluruhan antara UMKM Etnis Tionghoa, UMKM Etnis Arab dan UMKM Pribumi. Dalam penelitian ini akan membahas terkait UMKM Tionghoa dan UMKM Pribumi. UMKM Tionghoa bertahan cukup lama dibandingkan UMKM Pribumi. Permasalahan-permasalahan yang dihadapi UMKM Pribumi seperti produk industri kecil memiliki ciri atau karakteristik sebagai produk-produk dan kerajinan-kerajian dengan ketahanan yang pendek dan terbatasnya akses pasar menyebabkan produk yang dihasilkan tidak dapat dipasarkan secara kompetitif. Berbeda dengan UMKM Tionghoa yang meyakini bahwa keberhasilan usahanya dapat merek kontrol.

Dari pemaparan diatas, penulis tertarik untuk meneliti tentang pola pikir dan perilaku kewirausahaan UMKM Tionghoa dan Pribumi. Dengan merumuskan permasalahan apakah terdapat perbedaan pola pikir dan perilaku kewirausahaan antara UMKM Pribumi dengan UMKM Tionghoa. Penelitian ini mampu menjadi salah satu referensi dalam meningkatkan pengetahuan terkait kewirausahaan. Pada sesi berikutnya akan disajikan kajian literatur yang diikuti dengan penjelasan metode penelitian.

\section{KAJIAN LITERATUR}

Pada kajian literatur menguraikan mengenai teori yang digunakan, kerangka pemikiran dan hipotesis. Teori terkait dengan penelitian ini yaitu Etnis Pribumi, Etnis Tionghoa, Kewirausahaan, Mindset Kewirausahaan dan perilaku kewirausahaan.

\section{Literatur 1 Etnis Pribumi}

Suku bangsa (etnis) Bali merupakan suatu kelompok manusia yang terikat oleh kesadaran akan kesatuan budaya, sedangkan kesadaran itu diperkuat oleh adanya kesamaan bahasa. Walaupun ada kesadaran yang demikian, kebudayaan Bali mewujudkan banyak variasi dan perbedaan setempat. Disamping itu agama Hindu yang telah lama terintegrasikan ke dalam kebudayaan Bali, dirasakan pula sebagai unsur yang memperkuat adanya kesadaran akan kesatuan itu (Bagus, 2004). Oleh karena itu, kebudayaan etnis Bali tidak akan pernah terlepas dari dinamika sejarah Bali, yang memberikan warna pada setiap periode suatu peristiwa. Kebudayaan Bali banyak dipengaruhi oleh unsur-unsur luar yang membentuk tatanan nilai yang berlaku pada masyarakat Bali, sebab ciri asal yang bersikap kategoris adalah ciri khas yang mendasar dan secara umum menentukan kelompok etnis dan ini dapat diperikaran dari latar belakang asal-usulnya.

Menurut (Bagus, 2004) terkait dengan hal ini, Bali ditegaskan oleh para ahli yang menyatakan bahwa unsur-unsur atau pengaruh luar menjadi faktor dominan dalam konteks terbentuknya etnis Bali. Dalam hal ini tatanan nilai dari terbentuknya kebudayaan etnis Bali timbul dalam dunia birokrasi. Kekawin Jawa (Abad XIV), Nagarakertagama, memberikan beberapa bukti bagaimana kebudayaan Majapahit menyebar ke Bali. Pada abad ke-14, Bali adalah bagian dari Majapahit, meskipun keluasaan hegemoni yang nyata masih belum jelas, 
prasasti-prasasti Bali yang tertulis dalam bahasa Saksekerta dan bahasa Bali Kuna seperti halnya prasasti Blanjong dapat menjadi bukti. Pada waku itu bahasa yang digunakan untuk komunikasi berubah dari bahasa Bali ke bahasa Jawa Kuna dan tulisan-tulisan Jawa mulai ditiru. Perubahan-perubahan ini menjadi dominasi kebudayaan Jawa yang berlangsung berkenaan dengan perubahan-perubahan politik antara Jawa dan Bali. Demikian sekilas sejarah Bali yang melahirkan kebudayaan Bali didasari oleh pengaruh dari kebudayaan luar atau sebagai mainstream dari kebudayaan Bali, yakni kebudayaan Jawa Timur yang melalui pengaruh birokrasi administrative dari kerajaan Majapahit (Abad XIV). Jadi hal tersebut merupakan wujud kebudayaan Bali yang hingga kini masih bertahan adalah Agama Hindu yang terintegrasi ke dalam kebudayaan Bali. Hal ini menjadikan karakteristik daerah Bali yang sangat Nampak dari kehidupan agama Hindu, adat dan budayanya yang menyatu dalam suasana harmonis, atau dalam kata lain budaya Bali dijiwai oleh agama Hindu.

Etnis Bali memiliki kebudayaan dan kebiasaan yang unik, yang mana kebudayaan dan kebiasaan tersebut dapat dijadikan sebagai identitas atau jatidiri mereka. Kebudayaan yang dimiliki etnis Bali bermacam-macam, seperti kebudayaan yang sifatnya tradisional maupun bersifat modern. Etnis bali mampu masuk ke dalam wilayah etnis lain namun tidak pernah menghilangkan kebudayaan dan kebiasaan yang mereka miliki, karena kebudayaan dan kebiasaan tersebut telah mendarah daging dalam kehidupan mereka.

\section{Literatur 2 Etnis Tionghoa}

Keberhasilan orang-orang Cina sebenarnya sudah tampak sejak masa pemerintahan kolonial Hindia Belanda. Sejak tahun 1600-an terjadi imigrasi besar- besaran orang Cina ke Nusantara. Orang-orang Cina ini sengaja didatangkan oleh pemerintah kolonial belanda ke Nusantara (Pakpahan, 2008) dalam (Wisnu, 2013). Menurut Retno Winarni, sejarawan dari Cirebon (Ramadahan, www.kompasiana.com,9 Maret 2011) dalam (Wisnu, 2013) sebuah laporan resmi pihak Belanda dari tahun 1711 menyatakan bahwa orang-orang Cina berhasil menjadi pengusaha dengan membuat pabrik di wilayah Batavia. Mereka terkadang diandalkan oleh VOC (Verenigde Oost-Indische Compagnie) sebagai teknisi-teknisi. Hal ini dikarenakan VOC takut jika pribumi memiliki kekuatan maka pribumi akan memberontak terhadap VOC, maka dari itu sebisa mugkin VOC mengekang pribumi dan lebih mengutamakan orang-orang Cina untuk mengisi jabatan penting seperti Syahbandar, pejabat yang mengatur segala urusan di pelabuhan dari mulai penarikan cukai hingga perselisihan antar pedagang. Tidak dapat disangkal bahwa penduduk keturunan Cina sangat berperan dalam menggerakkan kehidupan ekonomi terutama dalam bidang industri serta perdagangan kecil dan menengah. Kedatangan orang Cina ke Indonesia (baik sebagai pedagang maupun sebagai buruh) membawa serta tradisi, tata kehidupan, norma-norma yang berlaku dalam masyarakat dan sikap fanatisme terhadap tradisi negeri leluhur. Bagi orang Cina perpindahan penduduk ini merupakan sebuah tradisi dan selalu mempunyai ciri. Orang Cina yang melakukan migrasi masih tetap mempertahankan diri sebagai orang Cina. Siswono Yudo Husodo dalam bukunya berjudul Warga Baru (Kasus Cina di Indonesia) dalam (Wisnu, 2013) mengatakan bahwa: Dimana pun orang-orang Cina tersebut bertempat tinggal, pedoman dan landasan hidup sosiokulturnya selalu berpatokan pada ajaran-ajaran filsafat Cina tradisional.

\section{Literatur 3 Kewirausahaan}

Seseorang wirausahawan selalu diharuskan mengharuskan menghadapi resiko atau peluang yang muncul, serta sering dikaitkan dengan tindakan yang kreatif dan inovatif. Wirausahawan adalah orang yang merubah nilai sumber daya, tenaga kerja, bahan dan faktor produksi lainya menjadi lebih besar daripada sebelumnya dan juga orang yang melakukan perubahan, inovasi dan cara-cara baru. Selain itu seorang wirausahawan menjalankan peran manajerial dalam kegiatannya, tetapi manajemen rutin pada oprasi yang sedang berjalan tidak digolongkan sebagai kewirausahaan ketika membentuk sebuah 
organisasi, tetapi selanjutnya menjalankan fungsi menejerial tanpa menjalankan fungsi kewirausahaan, jadi kewirausahaan bisa bersifat sementara atau kondisional.

Kewirausahaan merupakan kemampuan seseorang dalam menghadapi berbagai risiko dengan mengambil inisiatif untuk menciptakan dan melakukan hal-hal baru memalui pemanfaatan kombinasi berbagai sumber daya dengan tujuan untuk memberikan pelayanan yang terbaik kepada seluruh pemangku kepentingan dan memperoleh keuntungan sebagai konsekuensinya. Menurut Gitosardjono ada enam hakikat kewirausahaan yaitu:

1. Kewirausahaan adalah kemampuan menciptakan sesuatu yang baru dan berbeda.

2. Kewirausahaan adalah suatu nilai yang diwujudkan dalam perilaku yang dijadikan sumber daya, tenaga penggerak,tujuan, strategi, proses dan hasil bisnis.

3. Kewirausahaan adalah suatu proses dalam mengerjakan sesuatu kreatif dan inovatif yang bermanfaat dalam memberikan nilai lebih.

4. Kewirausahaan adalah suatu proses penerapan kreatifitas dan keinovasian dalam memecahkan persoalan dan menemukan peluang untuk memperbaiki, serta mengembangkan kehidupan usaha

5. Kewirausahaan adalah suatu nilai yang dibutuhkan untuk memulai sebuah usaha dan mengembangkan usaha yang dinyakini akan sukses.

6. Kewirausahaan adalah usaha menciptakan nilai tambah dengan jalan mengkombinasikan semua sumber daya secara kreatif dan inovatif untuk memenangkan persaingan.

\section{Literatur 4 Mindset Kewirausahaan}

Mindset adalah posisi atau pandangan mental seseorang yang mempengaruhi pendekatan orang tersebut dalam menghadapi suatu fenomena. Mindset terdiri dari seperangkat asumsi, metode, atau catatan yang dimiliki oleh seseorang atau kelompok yang tertanam dengan sangat kuat. Menurut Mulyadi (2007:71), mindset merupakan sikap mental mapan yang di bentuk melalui pendidikan, pengalaman dan prasangka. Menurut Gunawan (2007:14), mindset adalah beliefs that affect somebody's attitude; a set of beliefs orang a way of thinking that determine somebody's behavior and outlook (kepercayaan-kepercayaan yang mempengaruhi sikap seseorang; sekumpulan kepercayaan atau suatu cara berpikir yang menentukan perilaku dan pandangan, sikap, dan masa depan seseorang.

Mindset terdiri dari 2 suku kata, yaitu mind dan set. Mind merupakan kata dari bahasa inggris yang memiliki arti pikiran. Sedangkan kata set dalam Mindset secara tegas menunjukan sebuah kata kerja yang menggambarkan bagaimana seseorang secara perceptual dipersiapkan atau ditetapkan untuk mendeteksi dan menanggapi situasi tertentu (Cohen-Kdoshay dan Meiran, 2007). Menurut Gunawan (2014) pola pikir adalah inti dari selflearning atau pembelajaran diri. Inilah yang menentukan bagaimana memandang sebuah potensi, kecerdasan, tantangan dan peluang sebagai sebuah proses yang harus di upayakan dengan ketekunan, kerja keras, dan usaha untuk tercapainya tujuan. Wirausahawan yang sukses tentunya memiliki pola pikir (mindset) yang lebih maju dari orang-orang pada umumnya. Pentingnya pola pikir kewirausahaan digambarkan memungkinkan ada pendukung ide-ide baru untuk mendirikan lapangan kerja dengan ideide baru yang berharga, lalu adanya sumber daya yang dikembangkan untuk mendorong kegiatan wirausaha. Membentuk pola pikir kewirausahaan merupakan salah satu cara untuk mempertahankan daya saing organisasi ekonomi. Pola pikir kewirausahaan menunjukkan cara berpikir tentang bisnis dan peluang, guna menghadapi ketidakpastian.

\section{Literatur 5 Perilaku Kewirausahaan}

Perilaku manusia merupakan hasil daripada segala macam pengalaman serta interaksi manusia dengan lingkungannya yang terwujud dalam bentuk pengetahuan, sikap dan tindakan. Dengan kata lain, perilaku merupakan respon/reaksi seorang individu terhadap stimulus yang berasal dari luar maupun dari dalam dirinya. Respon ini dapat bersifat pasif 
(tanpa tindakan : berpikir, berpendapat, bersikap) maupun aktif (melakukan tindakan). Sesuai dengan batasan ini, perilaku kesehatan dapat di rumuskan sebagai bentuk pengalaman dan interaksi individu dengan lingkungannya, khususnya yang menyangkut pengetahuan dan sikap tentang kesehatan. Perilaku aktif dapat dilihat, sedangkan perilaku pasif tidak tampak, seperti pengetahuan, persepsi, atau motivasi. Beberapa ahli membedakan bentuk-bentuk perilaku ke dalam tiga domain yaitu pengetahuan, sikap, dan tindakan atau sering kita dengar dengan istilah knowledge, attitude, practice (Sarwono, 2004). Dari sudut biologis, perilaku adalah suatu kegiatan atau aktivitas organisme yang bersangkutan, yang dapat diamati secara langsung maupun tidak langsung. Perilaku manusia adalah suatu aktivitas manusia itu sendiri (Notoadmodjo, 2003).

Perilaku wirausaha didasarkan pada seperangkat nilai (kepercayaan) dan kebutuhan tertentu yang memberi individu motivasi intrinsik dan penentuan nasib sendiri untuk terlibat dalam perilaku kewirausahaan (Kirkley, 2016). Perilaku wirausaha terdiri dari aspek perilaku seorang entrepreneur seperti bersikap proaktif, kompetitif, inovatif, mengambil risiko, dan mandiri (Doye \& Bwisa, 2015). Pola Pikir bisa lahir dari banyak faktor seperti faktor keluarga, keadaan, pendidikan dan pengalaman. Secara garis besar, Pola Pikir Kewirausahaan dapat dikelompokkan menjadi tiga, yakni learning, pengembangan dan spiritualitas. Learning, Pelaku UMKM belajar dari kegagalan, pengalaman juga adaptasi dan inovasi. Pengembangan membuat Pelaku UMKM terus melakukan upaya pengambangan kualitas baik dari segi rasa masakan maupun pelayanan. Sedangkan spiritualitas membuat Pelaku UMKM berusaha untuk bersaing secara sehat dan lebih santai dalam memandang pesaing. Selain itu, mereka juga ikhlas dengan tidak hanya mengharapkan keuntungan semata, Pelaku UMKM juga lebih sabar dalam menghadapi situasi tertentu dan konsumen yang bermacam-macam karakternya (Dewi, 2018). Perilaku Kewirausahaan merupakan tindak lanjut yang dilakukan berdasarkan pola pikir atau mindset seseorang. Antara Mindset dan perilaku terdapat korelasi yang begitu kuat, karena mereka adalah dua hal yang berkesinambungan atau kontinyu.

Penelitian ini meneliti ada tidaknya perbedaan UMKM Tionghoa dan UMKM Pribumi dari segi pola pikir dan perilaku kewirausahaan. Bagan kerangka berpikir dijelaskan sebagai berikut:

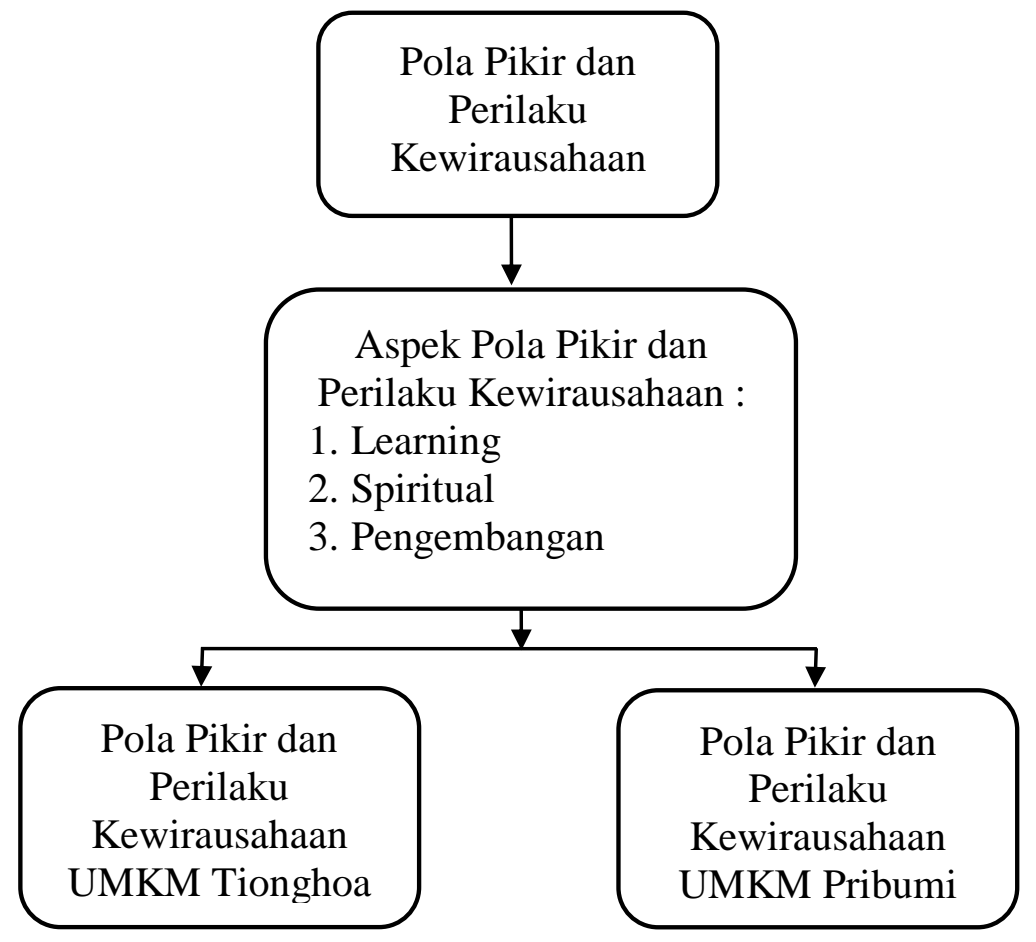

Gambar 1. Pola Pikir dan Perilaku Kewirausahaan UMKM Pribumi dan Tionghoa 


\section{METODE}

Jenis penelitian ini adalah kuantitatif komparatif. Untuk menganalisis penelitian, peneliti menggunakan angka-angka yang dideskripsikan dengan menguraikan kesimpulan yang didasari oleh angka yang diolah dengan metode statistik. Penelitian ini dilakukan pada UMKM yang terdapat di Kabupaten Buleleng. Populasi dalam penelitian ini adalah seluruh UMKM pribumi dan UMKM Tionghoa di Kabupaten Buleleng. Sampel yang digunakan adalah 30 UMKM Pribumi dan 30 UMKM Tionghoa. Metode sampling yang digunakan adalah Purposive Sampling dimana peneliti mempertimbangkan ciri-ciri dari responden guna memecahkan permasalahan penelitian serta dapat memberikan nilai yang lebih representatif. Jenis data yang digunakan adalah data kualitatif dan data kuantitatif. Sumber data yang digunakan adalah data primer dan data sekunder. Teknik pengumpulan data menggunakan dokumentasi dan kuesioner. Data dianalisis menggunakan software Statistical Package for the Social Sciences 17.

\section{HASIL DAN PEMBAHASAN}

\section{Hasil Penelitian}

\section{Nilai Indeks}

Analisis ini dilakukan untuk mendapatkan gambaran deskriptif mengenai responden penelitian ini, khususnya mengenai variabel-variabel penelitian yang digunakan. Analisis ini dilakukan dengan teknik analisis indeks, untuk menggambarkan persepsi responden atas item-item pertanyaan yang diajukan. Berdasarkan metode three-box untuk menentukan kriteria indeks persepsi responden, yang digunakan untuk interpretasi nilai indeks. Kriteria itu adalah sebagai berikut :

$$
\begin{array}{llll}
7,5-15 & = & \text { Rendah } \\
15,5-23 & = & \text { Sedang } \\
23,5-30 & = & \text { Tinggi }
\end{array}
$$

Dengan dasar ini, peneliti menentukan indeks persepsi responden terhadap variablevariable yang digunakan dalam penelitian ini. Tiga indikator telah digunakan dalam kajian terhadap pola pikir dan perilaku kewirausahaan, yaitu : Learning, Spiritual dan Pengembangan. Perhitungan angka indeks adalah seperti yang disajikan dalam tabel

\begin{tabular}{|c|c|c|c|c|c|}
\hline \multirow[t]{2}{*}{ Indikator } & \multicolumn{4}{|c|}{ Frekuensi jawaban responden } & \multirow[t]{2}{*}{ Indeks } \\
\hline & 1 & 2 & 3 & 4 & \\
\hline Belajar dari kegagalan & 0 & 9 & 13 & 8 & 22 \\
\hline Adaptasi dan inovasi & 0 & 8 & 19 & 3 & 21 \\
\hline $\begin{array}{l}\text { Belajar dari pengalaman } \\
\text { orang lain }\end{array}$ & 0 & 8 & 20 & 2 & 21 \\
\hline $\begin{array}{l}\text { Pemikiran rejeki ada di } \\
\text { tangan Tuhan }\end{array}$ & 1 & 10 & 17 & 2 & 20 \\
\hline Sabar & 1 & 8 & 16 & 5 & 21 \\
\hline Ikhlas & 2 & 4 & 18 & 6 & 22 \\
\hline $\begin{array}{l}\text { Mengutamakan kualitas dan } \\
\text { pelayanan }\end{array}$ & 1 & 5 & 17 & 7 & 23 \\
\hline \multicolumn{5}{|l|}{ 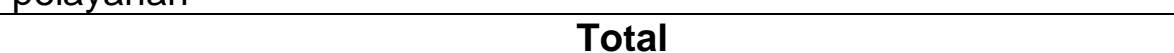 } & 21 \\
\hline
\end{tabular}
berikut :

Tabel 2. Nilai Indeks UMKM Pribumi

Sumber : Data Diolah 
Melihat tabel 2, Indikator pola pikir dan perilaku kewirausahaan UMKM Pribumi menunjukkan total angka indeks sebesar 21 yang artinya berada pada kriteria sedang. Sedangkan pada tabel 3 dapat dilihat bahwa indikator pola pikir dan perilaku kewirausahaan UMKM Tionghoa menunjukkan total angka indeks sebesar 24 yang artinya berada pada kriteria tinggi yang ditunjukkan pada tabel dibawah ini :

Tabel 3. Nilai Indeks UMKM Tionghoa

\begin{tabular}{|c|c|c|c|c|c|}
\hline \multirow[t]{2}{*}{ Indikator } & \multicolumn{4}{|c|}{ Frekuensi jawaban responden } & \multirow[t]{2}{*}{ Indeks } \\
\hline & 1 & 2 & 3 & 4 & \\
\hline Belajar dari kegagalan & 0 & 4 & 11 & 15 & 25 \\
\hline Adaptasi dan inovasi & 0 & 3 & 15 & 12 & 25 \\
\hline $\begin{array}{l}\text { Belajar dari pengalaman } \\
\text { orang lain }\end{array}$ & 0 & 6 & 14 & 10 & 24 \\
\hline $\begin{array}{l}\text { Pemikiran rejeki ada di } \\
\text { tangan Tuhan }\end{array}$ & 0 & 4 & 15 & 11 & 24 \\
\hline Sabar & 1 & 6 & 13 & 10 & 23 \\
\hline Ikhlas & 2 & 1 & 14 & 13 & 25 \\
\hline $\begin{array}{l}\text { Mengutamakan kualitas dan } \\
\text { pelayanan }\end{array}$ & 0 & 1 & 18 & 11 & 25 \\
\hline \multicolumn{5}{|l|}{ 年 } & 24 \\
\hline
\end{tabular}

Sumber : Data diolah

\section{Uji Normalitas}

Uji normalitas dilakukan untuk melihat kenormalan distribusi data variabel penelitian. Data yang terdistribusi secara normal akan membentuk distribusi normal, di mana data memusat pada nilai rata-rata dan median. Berikut merupakan hasil olahan data untik uji normalitas :

Tabel 4 Hasil Uji Normalitas

One-Sample Kolmogorov-Smirnov Test

\begin{tabular}{|ll|r|}
\hline & & \multicolumn{1}{|c|}{ Hasil } \\
\hline N & & 60 \\
& Mean & 3.05 \\
Most Extreme Differences & Std. Deviation & .472 \\
& Absolute & .107 \\
& Positive & .093 \\
Kolmogorov-Smirnov $Z$ & Negative & -.107 \\
Asymp. Sig. (2-tailed) & & .831 \\
\hline
\end{tabular}

a. Test distribution is Normal.

b. Calculated from data.

Berdasarkan tabel di atas hasil uji normalitas variabel menggunakan One Sample Kolmogorov-Smirnov Test menunjukkan bahwa pola pikir dan perilaku kewirausahaan UMKM Pribumi dan Tionghoa mempunyai koefisien $\mathrm{K}-\mathrm{Sz}=0.831$ dan signifikansinya sebesar 0,495, Oleh karena nilai signifikansi lebih besar dari 0,01 $(>=0,01)$, maka dapat dikatakan bahwa sebaran data berdistribusi normal. 


\section{Uji Homogenitas}

Menurut Ferdinand (2014) bahwa pengujian homogenitas menjadi sangat penting apabila peneliti bermaksud melakukan generalisasi untuk hasil penelitiannya serta penelitian yang data penelitiannya diambil dari kelompok-kelompok terpisah yang berasal dari satu populasi. Uji homogenitas dalam penelitian ini menggunakan levene test. Maka jika probabilitas $<0,01$ berarti Ho ditolak atau data tidak berdistribusi homogen.

\section{Tabel 5. Hasil Uji Homogenitas}

Test of Homogeneity of Variances
Hasil
\begin{tabular}{|r|r|r|c|}
\hline $\begin{array}{c}\text { Levene } \\
\text { Statistic }\end{array}$ & df1 & df2 & Sig. \\
\hline .000 & 1 & 58 & .997 \\
\hline
\end{tabular}

Pada tabel diketahui bahwa kolom sig. adalah 0,997 untuk variabel pola pikir dan perilaku kewirausahaan. Jika angka signifikasi di atas $0,01(0,997>0,01)$ maka dapat disimpulkan bahwa penelitian ini adalah dinyatakan homogen.

Uji Hipotesis

Hasil perhitungan uji perbedaan dua rata-rata data T-test dapat disajikan pada Tabel 6.

\section{Tabel 6. Hasil Uji Independent Sample Test}

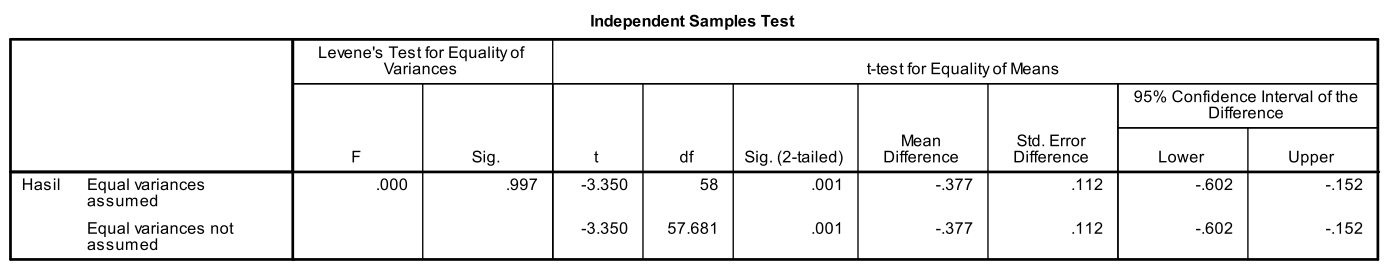

Berdasarkan hasil perhitungan diperoleh nilai sig $=0.001$ dengan t-hitung $=3.350$. Karena nilai sig $<1 \%$, maka dapat disimpulkan terdapat perbedaan yang signifikan antara Pola Pikir dan Perilaku Kewirausahaan pada UMKM Pribumi dan Tionghoa. Dengan demikian dapat dikatakan Pola Pikir dan Perilaku Kewirausahaan pada UMKM Pribumi dan Tionghoa pada dasarnya adalah berbeda, di mana pola pikir dan perilaku kewirausahaan UMKM Tionghoa lebih tinggi dibandingkan dengan pola pikir dan perilaku kewirausahaan UMKM Pribumi.

\section{Pembahasan}

Penelitian ini menemukan bahwa secara garis besar pola pikir dan perilaku kewirausahaan yang dimiliki oleh pelaku UMKM Pribumi dan Tionghoa dikelompokkan menjadi 3 yaitu learning, spiritualitas dan pengembangan. Belajar merupakan hal yang sangat penting dilakukan oleh pelaku UMKM. Walaupun usaha yang telah dijalankan berjalan dengan baik, tetap saja perlu dilakukan pembelajaran untuk mengikuti perkembangan jaman dan keberlanjutan usaha.Dari pola pikir ini para pelaku UMKM mewujudkannya dalam perilaku. Dalam konsep Mindset learning, para pelaku UMKM belajar dari kegagalan mereka. Kegagalan membuat mereka lebih teliti lagi dalam menjalankan bisnisnya agar kegagalan tersebut tidak lagi terulang. Dalam hal ini, UMKM Pribumi dan Tionghoa memiliki pemikiran yang sama yaitu kegagalan bisnis mereka dikarenakan faktor eksternal. Yang menjadi pembeda UMKM Tionghoa dan Pribumi yaitu UMKM Tionghoa berpikir bahwa keberhasilan suatu usaha dapat mereka kontrol tetapi UMKM Pribumi berpikir bahwa keberhasilan usahanya tidak dapat dikontrol. Selain itu, pelaku UMKM juga belajar dari pengalaman, entah pengalaman pribadi atau dari pengalaman orang lain. Pengalaman bisa menjadi kontrol untuk mengambil sebuah keputusan dalam menjalankan usaha. Selanjutnya adalah adaptasi dan inovasi. Para pelaku UMKM menganggap adaptasi 
adalah hal yang penting, setelah belajar maka selanjutnya yang dilakukan adalah beradaptasi dengan lingkungan. Kemajuan jaman membuat pelaku UMKM wajib untuk beradaptasi dengan perubahan. Setelah mampu beradaptasi selanjutnya adalah inovasi yaitu memberikan apa yang diinginkan konsumen sesuai dengan perkembangan yang ada. Kelemahan dari UMKM Pribumi adalah dari segi beradaptasi dan inovasi. Rendahnya olah pikir yang menciptakan sesuatu yang baru membuat UMKM Pribumi kalah saing dibanding UMKM Tionghoa. Bukan hanya dalam inovasi produk tetapi dalam inovasi tempat, perilaku pelaku UMKM dan pelayanan terhadap konsumen.

Dalam penelitian ini pengembangan adalah strategi untuk mengembangkan UMKM. Dalam mengembangkan suatu usaha strategi pengembangan sangatlah diperlukan. Strategi dapat dilakukan dengan meningkatkan kualitas produk yang ditawarkan masing-masing UMKM dan juga Pelayanan terhadap Konsumen. Selain itu, pelaku UMKM juga dapat mengembangkan kerjasama antar UMKM. Yang menjadi keunggulan dari UMKM Tionghoa adalah kerjasama yang kuat antar pelaku UMKM. UMKM Pribumi memiliki jaringan usaha dan kemampuan penetrasi pasar yang lemah sedangkan UMKM Tionghoa mempunyai konsep "Guan Xi" sebagai kunci dari jaringan dan penetrasi pasar yang kuat. Hendaknya UMKM Pribumi mampu menerapkan nilai positif dari konsep Guan Xi.

Hasil temuan di lapangan menjelaskan bahwa konsep spiritualitas sangat berpengaruh terhadap pola pikir dan perilaku kewirausahaan UMKM Pribumi dan Tionghoa. Tidak hanya berpikir tengtang keuntungan semata namun juga memberikan kepuasan kepada konsumen merupakan hal yang sangat penting dilakukan. UMKM Pribumi dan Tionghoa memiliki perbedaan dari segi spiritualitas. UMKM Pribumi masih menganggap bahwa sesama pelaku UMKM adalah pesaing. Persaingan memanglah hal yang wajar terjadi namun jangan sampai membebani pikiran yang akan merugikan usaha sendiri. Persamaan UMKM Pribumi dan Tionghoa adalah memegang teguh kepercayaan bahwa Tuhan telah menjamin rejeki setiap orang dan rejeki tidak akan pernah tertukar.

\section{SIMPULAN}

Berdasarkan hasil penelitian, dapat ditarik simpulan sebagai berikut: 1. Tingkat pola pikir dan perilaku kewirausahaan UMKM Tionghoa berada pada kategori tinggi sementara untuk pola pikir dan tingkat perilaku kewirausahaan UMKM pribumi berada pada kategori sedang. 2. Terdapat perbedaan signifikan tingkat pola pikir dan perilaku kewirausahaan antara UMKM Tionghoa dan UMKM Pribumi. Berdasarkan hasil penelitian, maka peneliti memberukan saran untuk UMKM Pribumi dapat meningkatkan pola pikir dan perilaku kewirausahaan yang berkaitan dengan pengembangan usaha. Untuk UMKM Tionghoa diharapkan dapat membangun kerjasama dengan UMKM lainnya guna mengembangan usahanya agar lebih sukses dan berkembang. Untuk peneliti selanjutnya disarankan untuk mengembangkan penelitian ini dengan menambahkan faktor-faktor yang menjadi kunci keberhasilan UMKM.

\section{REFERENSI}

Agung, Wahyu. 2010. Panduan SPSS 17.0 Untuk Mengolah Penelitian Kuantitatif. Yogyakarta : Garailmu.

Amalia, Fitri. 2015. Etos Budaya Kerja Pedagang Etnis Tionghoa di Pasar Semawis Semarang. Universitas Negeri Semarang.

Andriyanto .R, Rovi. 2014. Perbedaan Pola Pikir Kewirausahaan dan Adversity Quotient Pada Mahasiswa Psikologi Universitas Negeri Malang Yang Berorientasi Terhadap Pencipta Lapangan Kerja Dan Pencari Kerja. Universitas Negeri Malang.

Cohen, Aaron. 2007. "Dynamics between Occupational and Organizational Commitment in the Context of Flexible Labor Markets: A Review of the Literature and Suggestions for a Future Research Agenda", Research Result: Institut Technik und Bildung, Bremen: March 2007, p. 1-28 
Dewi, Lita Rohma. 2018. Mindset dan Perilaku Kewirausahaan Wanita Pengusaha Jasa Boga di Yogyakarta. Universitas Islam Indonesia. Yogyakarta.

Doye, N.C. \& Bwisa, M. 2015. The Relationship Between Entrepreneurial Behavior and Performance of Camel Rearing Enterprises in Turkana County, Kenya. International Journal of Technology Enhancements and Emerging Engineering Research, Vol 3, Issue 09. 149-157

Ferdinand, Augusty. 2014. Metode Penelitian Manajemen, Edisi V, Badan Penerbit Universitas Diponegoro, Semarang

Gunawan, Imam. 2014. METODE PENELITIAN KUALITATIF: Teori dan Praktik. Jakarta: Bumi Aksara

Kirkley, W.W. 2016. Entrepreneurial Behavior: The Role of Value. International Journal of Entrepreneurial Behavior \& Research, Vol. 22 No. 3, Pp. 290-328

Maharani, Dian Mega. 2013. Perilaku Kewirausahaan Pedagang Etnis Cina dan Pedagang Etnis Jawa di Pasar Yaik Permai Semarang. Universitas Negeri Semarang.

Nagel, P. Julius F. 2013. Studi Eksploratori Pola Atribusi Keberhasilan dan Kegagalan Bisnis: Sebuah Persepsi dari Pengusaha Kecil Dan Mikro Pribumi Dan Tionghoa Di Surabaya. Proceeding Seminar Nasional ISBN: 978-979-636-147-2 dan Call For Papers.

Ngurah Bagus, I Gusti. 2004. Kebudayaan Bali: Manusia dan Kebudayaan Indonesia. Koentjaraningrat (ed.). Jakarta: Djambatan

Purwati, Rita. 2014. Identification Of Franchisors Entrepreneurial Traits And Mindset. Universitas Indonesia.

Rambe, Yunita Sari. 2017. Pengaruh Mindset dan Inovasi Terhadap Keberhasilan Usaha Pakaian di Jalan Halat Medan. Universitas Sumatera Utara

Salim, Agus. 2006. Stratifikasi Etnik (Kajian Mikro Sosiologi Interaksi etnis Jawa dan Cina. Semarang: Tiara Wacana.

Suaidy, Helmi. Lewenussa, Ramli. 2019. Pengaruh Pola Pikir (Mindset) Kewirausahaan Terhadap Motivasi dan Keterampilan Wirausaha Mahasiswa Program Studi Manajemen Universitas Muhammadiyah Sorong. Sentralisasi Volume 8 ( 1 ) : Hal 1-17.DOI: https://doi.org/10.33506/sl.v811.385 Helmi Suaidy. Fakultas Ekonomi Universitas Muhammadiyah Sorong.

Sudibyo, Bastian. 2016. Perbedaan Sikap Kewirausahaan antara Etnis Tionghoa dan Etnis Jawa pada Mahasiswa Fakultas Psikologi Universitas Kristen Satya Wacana. Universitas Kristen Satya Wacana Salatiga.

Suharyono. 2017. Sikap dan Perilaku Wirausahawan. Jurnal IImu dan Budaya, Vol. 40, No.56,Mei 2017. Universitas Nasional Jakarta.

Susanti. 2016. Etos Kerja Pedagang Tionghoa di Peunayong. Fakultas Ushuluddin Dan Filsafat Universitas Islam Negeri Ar-Raniry Darussalam - Banda Aceh 2016 M/1437 h 